\title{
Kinetic study of a $\beta$-mannanase
} (a) CrossMark from the Bacillus licheniformis HDYM-04 and
its decolorization ability of twenty-two
structurally different dyes

Jingping $\mathrm{Ge}^{1 \dagger}$, Renpeng Du ${ }^{1,2+}$, Dan Zhao ${ }^{1}$, Gang Song ${ }^{1}$, Man Jin ${ }^{1}$ and Wenxiang Ping ${ }^{1 *}$

\begin{abstract}
Background: The microbial $\beta$-mannanases have been increasingly exploited for bioconversion of biomass materials and various potential industrial applications, such as bleaching of softwood pulps, scouring and desizing, food and feed additive, and oil and textile industries. In this paper, a $\beta$-mannanase was characterization from the bacteria, Bacillus licheniformis HDYM-04, which was a high $\beta$-mannanase-producing strain $(576.16 \pm 2.12 \mathrm{U} / \mathrm{mL}$ at $48 \mathrm{~h}$ during fermentation).

Methods: The michaelis constant $\left(K_{m}\right)$ and maximum velocity $\left(V_{\text {max }}\right)$ of $\beta$-mannanase were determined. The effect of organic solvents, inhibitors, detergents, chelating agents, oxidizing agents and reducing agents on the stability of enzyme were determined. The degradation of twenty-two structurally different dyes by the purified $\beta$-mannanase produced by HDYM-04 was determined by full spectrum scan among 200-1000 nm at 0 min and 10 min, respectively.

Results: $\beta$-Mannanase produced by HDYM-04 was highly specific towards glucomannan, where as exhibited low activity towards guar gum. Michaelis constant $\left(K_{m}\right)$ and maximum velocity $\left(V_{\max }\right)$ of glucomannan substrate were $2.69 \mathrm{mg} / \mathrm{ml}$ and $251.41 \mathrm{U} / \mathrm{mg}$, respectively. The activity of different organic solvents showed significantly difference $(p<0.05)$. It retained $>80 \%$ activity in dimethyl sulfoxide, acetone, chloroform, benzene, hexane. In the presence of solvents, citric acid, ethylene diamine teraacetic acid and potassium iodide, it retained $>80 \%$ residual activity. Twenty-two structurally different dyes could be effectively decolourised by $\beta$-mannanase within $12 \mathrm{~h}$, in which methyl orange $(99.89 \pm 2.87 \%)$, aniline blue $(90.23 \pm 2.87 \%)$ and alizalin $(83.63 \pm 2.89 \%)$ had high decolorization rate.

Conlusion: The obtained results displayed that the $\beta$-mannanase produced by HDYM-04 showed high stability under different chemical reagents and was found to be capable of decolorizing synthetic dyes with different structures. So, the reported biochemical properties of the purified $\beta$-mannanase and its rapid decolorizations of dyes suggested that it might be suitable for industrial wastewater bioremediation.
\end{abstract}

Keywords: $\beta$-Mannanase, Bacillus licheniformis, Characterization, Dye decolorization

\section{Background}

$\beta$-Mannanase (endo-1,4- $\beta$-D-mannanase, EC 3.2.1.78) is a hydrolase that catalyzes the random hydrolysis of $\beta$-1,4-mannosidic linkages in the main chain of

\footnotetext{
*Correspondence: wenxiangp@aliyun.com

${ }^{\dagger}$ Jingping Ge and Renpeng Du have contributed equally to this work

${ }^{1}$ Key Laboratory of Microbiology, College of Life Science, Heilongjiang University, Harbin 150080, People's Republic of China

Full list of author information is available at the end of the article
}

$\beta$-1,4-D-mannan and releases linear/branched oligosaccharides of various lengths, and it could be classed to the glycosyl hydrolase (GH) families 5 and 26 based on amino acid sequence similarities (Van Zyl et al. 2010; Cantarel et al. 2009). $\beta$-mannanases have been characterized from a wide range of organisms, including invertebrate, plants, filamentous fungi, yeasts and bacteria. There has been growing interest over the years in the industrial potential of $\beta$-mannanase degrading enzymes, 
especially microbial $\beta$-mannanase (Wang et al. 2010a, b; Chauhan et al. 2012). Microbial $\beta$-mannanases are the primary endo-type enzymes responsible for degradation of mannan polysaccharides (Liepman et al. 2007; Scheller and Ulvskov 2010). The microbial $\beta$-mannanases have been increasingly exploited for bioconversion of biomass materials and various potential industrial applications, such as bleaching of softwood pulps, scouring and desizing, food and feed additive, and oil and textile industries due to the various advantages it can act in a wide range of $\mathrm{pH}$ and temperature because of which they play important roles in basic research (Dhawan and Kaur 2007; Zhou et al. 2012). So far, various microbial $\beta$-mannanases from Streptomyces sp. (Takahash et al. 1984), Bacillus subtilis (Jiang et al. 2006), Aplysia kurodai (Zahura et al. 2011), Bacillus licheniformis (Songsiriritthigul et al. 2010) and Trichoderma harzianum (Ferreira and Ferreira 2004) have been purified and characterized.

Synthetic dyes are classified as anthraquinone, azo, heterocyclic, triphenylmethane (TPM) dyes, and extensively used in several industries including textile, cosmetic, paper, printing, leather-dyeing, pharmaceutical and food industries (Chauhan et al. 2014a, b), but they have caused a serious environmental pollution. Moreover, the exiting dyes usually come from synthetic origin and contribute to more complicate molecular structures making them difficult to biodegrade which most of them are toxic, mutagenic and carcinogenic (Brown and De Vito 1993). The process of dye decolorization based on enzyme is an efficient method and is attracting increasing interest (Erkurt et al. 2007). By means of enzymatic catalyzed oxidative reactions, $\beta$-mannanase can detoxify phenolic contaminants (Asgher et al. 2008). At present, a lot of studies have focused on microbial enzymes. Certain fungal laccases combined with synthetic or natural mediators have been reported to proved to be suitable tools for textile effluent and dye removal treatments (Kaushik and Malik 2009). Although the $\beta$-mannanases from Bacillus have been already well characterized, there is still absence of information on the enzyme's kinetic properties and factors that influence stability and the use of $\beta$-mannanases is still restricted due to high-production costs and low yields (Zhang et al. 2000; Zakaria et al. 1998). Surprisingly, no studies have been implemented to estimate $\beta$-mannanases from Bacillus licheniformis that may take part in the decolorize and biodegrade dyes.

In our previous studies, a $\beta$-mannanase from B.licheniformis HDYM-04 was purified (Ge et al. 2016). However, the stability of chemical reagents and application performances of $\beta$-mannanase have not been studied. The aim of this study was to carry out preliminary investigation of biocatalytic kinetic properties, stability of organic solvents, including inhibitors, detergents, chelating agents and oxidizing agents and decolorization of multifarious dyes of $\beta$-mannanase from B.licheniformis HDYM-04. Investigation of the application performance of $\beta$-mannanase would enhance the potential usability in industrial processing.

\section{Methods}

\section{Microorganism and cultivation}

B.licheniformis HDYM-04 was isolated from flax-retting water in Bayan County, Heilongjiang Province, P.R. China. This strain was preserved in Key Laboratory of Microbiology, College of Life Science, Heilongjiang University. For the seed culture, one colony was inoculated into $200 / 250 \mathrm{~mL}$ liquid medium ( $1 \%$ peptone, $0.5 \%$ yeast extract and $1 \% \mathrm{NaCl} ; \mathrm{w} / \mathrm{v}$ ) and incubated at $37^{\circ} \mathrm{C}$ overnight. $2 \mathrm{~mL}$ seed liquid of strain HDYM-04 was inoculated into the liquid KGM medium which contained (1\% konjac powder, $1 \%$ peptone, $0.5 \% \mathrm{~K}_{2} \mathrm{HPO}_{4} \cdot 3 \mathrm{H}_{2} 0,0.02 \%$ $\left.\mathrm{MgSO}_{4} \cdot 7 \mathrm{H}_{2} \mathrm{O}, \mathrm{pH} 8.0 ; \mathrm{w} / \mathrm{v}\right)$. The incubation lasted $48 \mathrm{~h}$ under the conditions at $37^{\circ} \mathrm{C}$ with agitation speed of 160 $\mathrm{r} / \mathrm{min}$.

\section{Protein and enzyme assays}

Protein concentration was determined according to the method of Bradford using bovine serum albumin (BSA) as the standard (Bradford 1976). The protein eluted with column chromatography was monitored by taking absorbance at $595 \mathrm{~nm}$. Briefly, $0.1 \mathrm{~mL}$ sample was added to $5 \mathrm{~mL}$ Comassie Brilliant blue solution $(0.1 \%$, w/v) containing phosphoric acid ( $85 \%, \mathrm{w} / \mathrm{v})$ and mixed. Then, it was allowed to stand at room temperature for $2 \mathrm{~min}$ and the absorbance was measured at $595 \mathrm{~nm}$ against blind sample which was formed by using pure water instead of enzyme. The $\beta$-mannanase activity of HDYM-04 was assayed by measuring the amount of reducing sugars released by the enzyme using dinitrosalicylic (DNS) method (Miller 1959). The enzyme assay mixture contained $0.9 \mathrm{ml}$ of $0.5 \%$ (w/v) konjac powder without reducing sugar substrate buffer $(0.5 \%$ konjac powder in citric acid- $\mathrm{Na}_{2} \mathrm{HPO}_{4}$ buffer, $\mathrm{pH} 4.0$ ) and $0.1 \mathrm{~mL}$ of appropriately diluted enzyme. The reaction mixture was maintained at $55^{\circ} \mathrm{C}$ for $30 \mathrm{~min}$, and then, $3 \mathrm{~mL}$ of DNS reagent was added and boiled for $5 \mathrm{~min}$ and constanted volume to $25 \mathrm{~mL}$. After cooling to room temperature, the absorbance at $550 \mathrm{~nm}$ was measured. One unit of enzyme activity was defined as the amount of enzyme that produced $1 \mu \mathrm{mol}$ of reducing sugar as a D-mannose standard per minute by $1 \mathrm{~mL}$ of enzyme. The crude $\beta$-mannanase produced by HDYM-04 was obtained according to "Microorganism and cultivation". The precipitated enzyme was dialysed and monitored at $550 \mathrm{~nm}$ followed by activity assay. The crude enzyme was purified to homogeneity by using combination of acetone precipitation, ion-exchange 
chromatography (DEAE-Cellulose, D3764, Sigma, USA) and gel filtration (Sephadex G-75, Sigma, USA) (Ge et al. 2016).

\section{Determination of kinetic properties}

The michaelis constant $\left(K_{m}\right)$ and maximum velocity $\left(V_{\max }\right)$ of $\beta$-mannanase produced by HDYM-04 were determined in $0.1 \mathrm{~mol} / \mathrm{L}$ Tris- $\mathrm{HCl}$ buffer $(\mathrm{pH} 8.0)$ containing $0.2-1 \mathrm{mg} / \mathrm{mL}$ substrates (amorophophallus konjac and guar gum), after incubation with $3 \mathrm{~mL}$ purified $\beta$-mannanase produced by HDYM-04 at $60{ }^{\circ} \mathrm{C}$ for $10 \mathrm{~min}$, and then, $3 \mathrm{~mL}$ of DNS reagent was added and boiled for $5 \mathrm{~min}$ and constanted volume to $25 \mathrm{~mL}$. After cooling to room temperature, the absorbance at $550 \mathrm{~nm}$ was measured. The data were plotted according to the Lineweaver-Burk method (Zeilinger et al. 1993). Each data was an average of three independent experiments, and every test included three samples.

\section{Effect of organic solvents on the stability of $\beta$-mannanase produced by HDYM-04}

To determine the effect of organic solvents (dimethyl sulfoxide, ethanol, formaldehyde, acetone, chloroform, benzene, xylene, hexane, petroleum ether) at $50 \%$ concentration on the stability of $\beta$-mannanase produced by HDYM-04, $1 \mathrm{~mL}$ of suitably diluted purified enzyme was mixed with $1 \mathrm{~mL}$ of different organic solvents and then incubated at $37^{\circ} \mathrm{C}$ for $3 \mathrm{~h}$ with constant shaking $(150 \mathrm{r} / \mathrm{min})$.

\section{Effect of inhibitors, detergents, chelating agents, oxidizing} agents and reducing agents on $\beta$-mannanase activity

To study the effects of inhibitors (citric acid, oxalic acid, phenylmethyl sulfonyl fluoride (PMSF), sodium thioglycolate, hydrogen), detergents (cetyl trimethyl ammonium bromide, polyethylene glycol), chelating agents (sodium citrate, ethylene diamine teraacetic acid, sodium azide), oxidizing agents (hydrogen peroxide, ammonium persulfate, potassium iodide), reducing agents (ascorbic acid, dithiothreitol (DTT)) at $1 \mathrm{mM}$ concentrations on the enzyme activity, suitably diluted purified enzyme was preincubated with reagents for $1 \mathrm{~h}$ at $37^{\circ} \mathrm{C}$ with constant shaking (150 r/min).

\section{Decolorization of synthetic dyes by the $\beta$-mannanase produced by HDYM-04}

All the tested dyes were purchased from Sigma Company, detailed information was shown in Table 1 . The degradation of twenty-two structurally different dyes by the purified $\beta$-mannanase produced by HDYM-04 was determined by full spectrum scan among 200-1000 nm at $0 \mathrm{~min}$ and $10 \mathrm{~min}$, respectively. The decolorization of test dyes were calculated at $37^{\circ} \mathrm{C}$ for 6 and $12 \mathrm{~h}$ on rotary $(160 \mathrm{r} / \mathrm{min})$, respectively. The reaction mixture for the standard assay contained respective dye $(0.05 \mathrm{mg} / \mathrm{mL})$ in disodium hydrogen phosphate-citric acid buffer at $\mathrm{pH}$ 6.0 and the enzyme solution $(5896.4 \mathrm{U} / \mathrm{mL})$ in a total volume of $6 \mathrm{~mL}$. The decolorization rate of dye, expressed as dye decolorization (\%), was calculated as the formula: decolorization $(\%)=\left(1-\mathrm{A} / \mathrm{A}_{0}\right) \times 100 \%$, where $\mathrm{A}_{0}$ : initial absorbance of the dye, $\mathrm{A}$ : absorbance of the dye along the time. All experiments were performed in triplicate.

\section{Statistical analysis}

All tests were performed in three replications. Average \pm standard errors of all obtained date were defined. The average standard errors of the data were expressed. SPSS version 10.0 software (SPSS Inc., Chicago, IL., USA) was used for the statistical analysis; and Tukey test was performed for determining the significant differences at $95 \%$ confidence interval $(p<0.05)$.

\section{Results}

Kinetic parameters of $\beta$-mannanase produced by HDYM-04 The $\beta$-mannanase produced by HDYM-04, which was a high $\beta$-mannanase-producing strain, and the maximal $\beta$-mannanase activity was $576.16 \pm 2.12 \mathrm{U} / \mathrm{mL}$ at $48 \mathrm{~h}$ during fermentation (Fig. 1). Michaelis constant could reflect the strength of enzyme substrate affinity. The kinetics $\left(V_{\max }\right.$ and $\left.K_{\mathrm{m}}\right)$ of low viscosity amorophophallus konjac and guar gum hydrolysis by the purified $\beta$-mannanase produced by HDYM-04 were calculated from Lineweaver-Burk double reciprocal plots (Fig. 2). The $K_{\mathrm{m}}$ and $V_{\max }$ values for the purified $\beta$-mannanase produced by HDYM-04 on amorophophallus konjac and guar gum were 2.69 and $19.26 \mathrm{mg} / \mathrm{mL}$, and 251.41 and $588.24 \mathrm{umol} / \mathrm{min} \mathrm{mL}$, respectively. Higher $K_{\mathrm{m}}$ value of guar gum than amorophophallus konjac suggested the higher affinity of amorophophallus konjac to the purified $\beta$-mannanase produced by HDYM-04, which was highly in accordance with the result of substrate specificity.

\section{Effect of organic solvents on the stability of $\beta$-mannanase} The effects of organic solvents on the $\beta$-mannanase activity produced by HDYM-04 are shown in Fig. 3. In the present study, $\beta$-mannanase produced by HDYM-04 remined stable after $3 \mathrm{~h}$ of preincubation with most of the tested organic solvents. The activity of different organic solvents showed significantly difference $(p<0.05)$. It retained $>80 \%$ activity in dimethyl sulfoxide, acetone, chloroform, benzene, hexane. The enzyme activity significantly higher in dimethyl sulfoxide $(93.4 \pm 1.74 \%)$ and hexane $(94.34 \pm 1.19 \%)$ compared to that in other organic solvents $(p<0.05)$. Furthermore, ethanol induced decrease of the enzyme activity to $63.21 \pm 2.05 \%$, and xylene, which is a strong reducing agent on disulphide bonds, strongly inhibited the enzyme to $43.33 \pm 1.53 \%$. 
Table 1 Characteristics of dyes tested in this work

\begin{tabular}{|c|c|c|c|}
\hline Dyes & Type & $\lambda_{\max }(\mathrm{nm})$ & Chemical formular \\
\hline Orange G6 & Azo & 469 & $\mathrm{C}_{16} \mathrm{H}_{10} \mathrm{~N}_{2} \mathrm{Na}_{2} \mathrm{O}_{7} \mathrm{~S}_{2}$ \\
\hline Orange I & Azo & 467 & $\mathrm{C}_{16} \mathrm{H}_{12} \mathrm{~N}_{2} \mathrm{O}_{4} \mathrm{~S} \cdot \mathrm{Na}$ \\
\hline Methyl orange & Azo & 461 & $\mathrm{C}_{14} \mathrm{H}_{15} \mathrm{~N}_{3} \mathrm{NaO}_{3} \mathrm{~S}$ \\
\hline Ponceau S & Azo & 501 & $\mathrm{C}_{13} \mathrm{H}_{9} \mathrm{~N}_{3} \mathrm{NaO}_{5}$ \\
\hline Alizarin yellow $R$ & Azo & 373 & $\mathrm{C}_{22} \mathrm{H}_{14} \mathrm{~N}_{6} \mathrm{Na}_{2} \mathrm{O}_{9} \mathrm{~S}_{2}$ \\
\hline Solvent red 24 & Azo & 232 & $\mathrm{C}_{24} \mathrm{H}_{20} \mathrm{~N}_{4} \mathrm{O}$ \\
\hline Amaranth & Azo & 508 & $\mathrm{C}_{34} \mathrm{H}_{32} \mathrm{ClN}_{3} \mathrm{NaO}_{6} \mathrm{~S}_{2}$ \\
\hline Chromotrope 2R & Azo & 504 & $\mathrm{C}_{16} \mathrm{H}_{10} \mathrm{~N}_{2} \mathrm{Na}_{2} \mathrm{O}_{8} \mathrm{~S}_{2}$ \\
\hline Alizarin & Anthraquinone & 417 & $\mathrm{C}_{14} \mathrm{H}_{7} \mathrm{NaO}_{7} \mathrm{~S}$ \\
\hline Methylene blue & Anthraquinone & 682 & $\mathrm{C}_{16} \mathrm{H}_{18} \mathrm{~N}_{3} \mathrm{ClS}$ \\
\hline Fast green3 & Triaromatic methane & 618 & $\mathrm{C}_{37} \mathrm{H}_{34} \mathrm{~N}_{2} \mathrm{O}_{10} \mathrm{~S}_{3} \mathrm{Na}_{2}$ \\
\hline Aniline blue & Triaromatic methane & 582 & $\mathrm{C}_{32} \mathrm{H}_{25} \mathrm{~N}_{3} \mathrm{Na}_{2} \mathrm{O}_{9} \mathrm{~S}_{3}$ \\
\hline Coomassie brilliant blue & Triaromatic methane & 595 & $\mathrm{C}_{45} \mathrm{H}_{44} \mathrm{~N}_{3} \mathrm{O}_{7} \mathrm{~S}_{2} \mathrm{Na}$ \\
\hline Brilliant green & Triaromatic methane & 623 & $\mathrm{C}_{27} \mathrm{H}_{34} \mathrm{~N}_{2} \mathrm{O}_{4} \mathrm{~S}$ \\
\hline Eosin & Triaromatic methane & 522 & $\mathrm{C}_{20} \mathrm{H}_{6} \mathrm{Br}_{4} \mathrm{Na}_{2} \mathrm{O}_{5}$ \\
\hline Water-soluble melanin & Cyanine & 533 & $\mathrm{C}_{24} \mathrm{H}_{19} \mathrm{~N}_{4}$ \\
\hline Eosin $Y$ & Three aryl methyl & 523 & $\mathrm{C}_{36} \mathrm{H}_{27} \mathrm{~N}_{3} \mathrm{O}_{5} \mathrm{Br}_{4} \mathrm{~S}$ \\
\hline Bromothmol blue & Three aryl methyl & 420 & $\mathrm{C}_{27} \mathrm{H}_{28} \mathrm{Br}_{2} \mathrm{O}_{5} \mathrm{~S}$ \\
\hline Bromophenol blue & Three aryl methyl & 422 & $\mathrm{C}_{19} \mathrm{H}_{10} \mathrm{Br}_{4} \mathrm{O}_{5} \mathrm{~S}$ \\
\hline 5,5'-Dibromo-o-cresolsulfonphthalein & Three aryl methyl & 648 & $\mathrm{C}_{21} \mathrm{H}_{16} \mathrm{Br}_{2} \mathrm{O}_{5} \mathrm{~S}$ \\
\hline Safranine $T$ & Heterocyclic & 530 & $\mathrm{C}_{20} \mathrm{H}_{19} \mathrm{~N}_{4} \mathrm{Cl}$ \\
\hline Neutral red & Heterocyclic & 440 & $\mathrm{C}_{15} \mathrm{H}_{17} \mathrm{ClN}_{4}$ \\
\hline
\end{tabular}

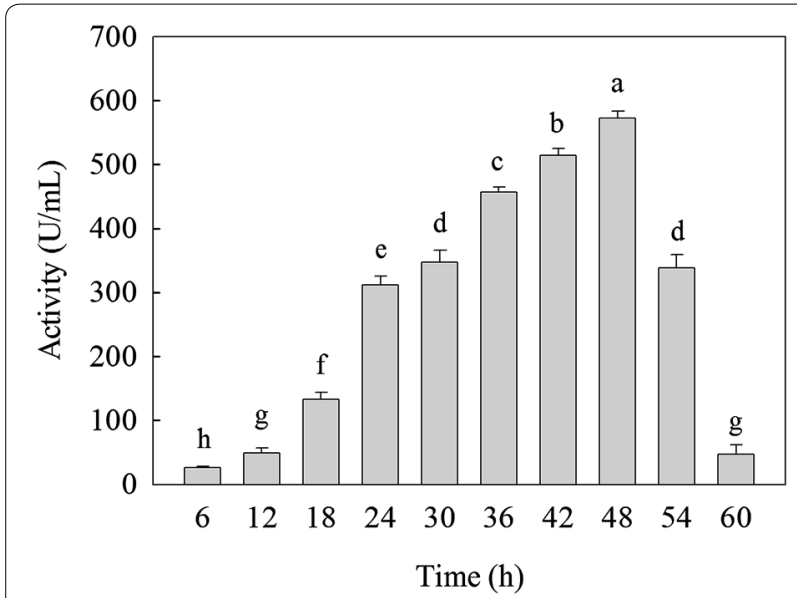

Fig. 1 Konjac gum to determine the incubation time of fermentation. Different letters represent significant differences $(p<0.05)$ relative to the control

Effect of inhibitors, detergents, chelating agents, oxidizing agents and reducing agents on $\beta$-mannanase activity

The $\beta$-mannanase produced by HDYM-04 was found to be stable with most of the tested agents (Table 2). The inhibition of different reagents showed significantly difference $(p<0.05)$. In the presence of solvents; citric acid, ethylene diamine teraacetic acid and potassium iodide, it retained $>80 \%$ residual activity. Furthermore, phenylmethyl sulfonyl fluoride and dithiothreitol induced decrease of the $\beta$-mannanase activity to $26.98 \pm 2.44$ and $27.63 \pm 2.41 \%$, and cetyl trimethyl ammonium bromide, which is a strong detergents on disulphide bonds, strongly inhibited the enzyme to $14.15 \pm 1.21 \%$. However, in the presence of solvents polyethylene glycol and sodium citrate, $\beta$-mannanase activity decreased to $79.62 \pm 2.47$ and $78.87 \pm 3.23 \%$, respectively.

\section{Decolorization of synthetic dyes}

The decolorization of various dyes with different structural patterns were investigated by using purified $\beta$-mannanase produced by HDYM-04. Our system was able to efficiently degrade a number of commercial textile dyes. Table 3 showed the degradation of twenty-two structures of different dyes including azo, anthraquinone, arylmethyl and other structures of dyes by the purified $\beta$-mannanase from HDYM-04. The best decolorization overall (80-100 \%) were obtained with reactive methyl orange, aniline blue and alizalin within $12 \mathrm{~h}$ (Fig. 4). The remaining nineteen dyes were degraded on different extend within $12 \mathrm{~h}$ as revealed. Somewhat lower decolorization (30-70 \%) was obtained with basic violet 3 , ponceau S, water-soluble melanin, coomassie brilliant blue 

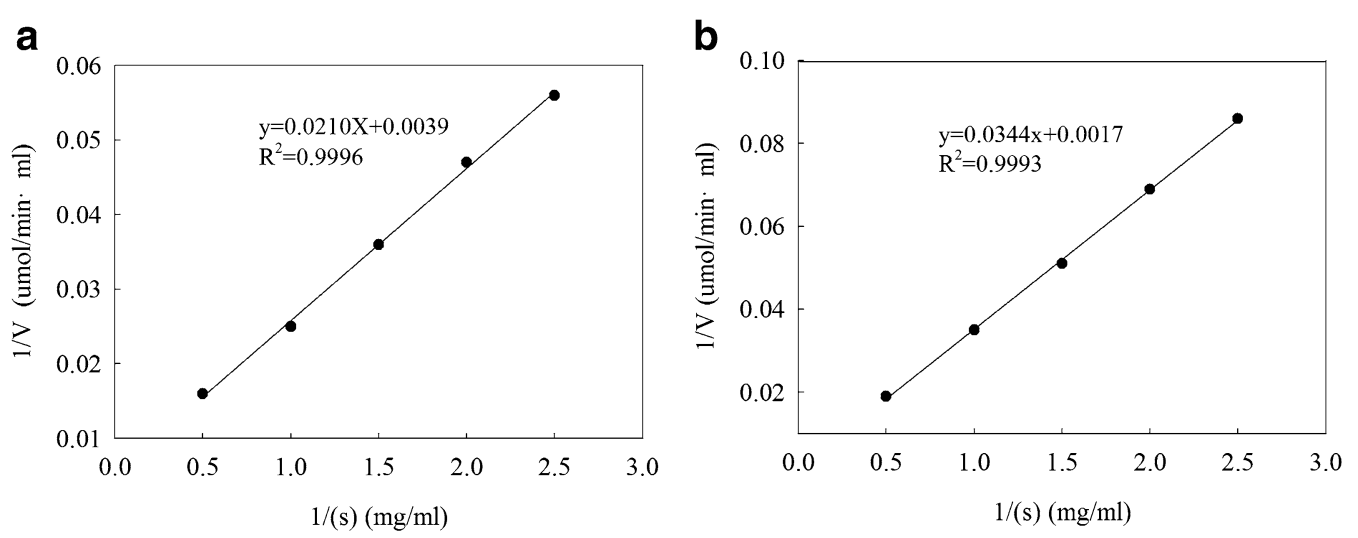

Fig. 2 Amorophophallus konjac (a) and guar gum (b) as the substrate Lineweaver-Burk double bottom. The data were expressed with Lineweaver-Burk plot, and $K_{m}$ and $V_{\max }$ values were calculated using the nonlinear regression

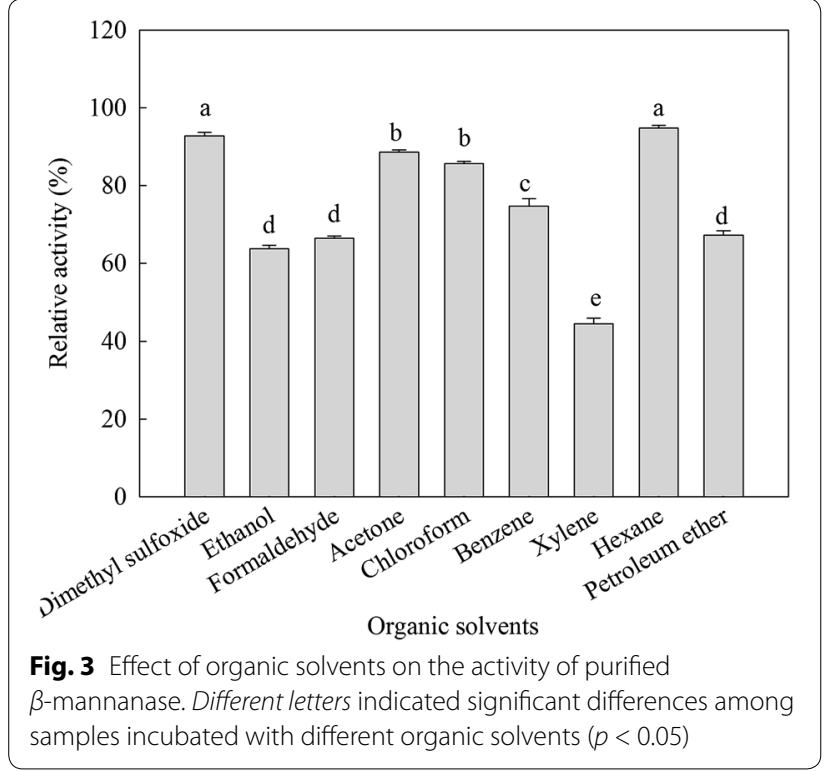

and brilliant green. This could be due to enzyme inhibition (by some products generated in the decolorization process) or substrate inhibition. However, the eosin, amaranth, chromotrope $2 \mathrm{R}$, alizarin yellow $\mathrm{R}$, methylene blue, fast green 3 and neutral red were nearly not decolorized by the purified $\beta$-mannanase from HDYM04 , which was probably due to the complexity of dye structures.

\section{Discussion}

In conclusion, this study reported the some characterization of a $\beta$-mannanase produced by HDYM- 04 . The property of enzyme to maintain a high production at a short time was interesting from the point of view of industry. To the best of our knowledge, this was the first report about the production of $\beta$-mannanase from HDYM-04 at $37^{\circ} \mathrm{C}$. Similarly, Paenibacillus sp. DZ23 and B.subtilis NM-39 produced enzyme at $37{ }^{\circ} \mathrm{C}$ with glucomannan and locust bean gum as the substrate (Chandra et al. 2011; Mendoza et al. 1994). Other B.subtilis strains separated so far from producing maximum enzyme at below $50{ }^{\circ} \mathrm{C}$ (Zhou et al. 2012). Some B.subtilis strains can produced enzyme at up to $45^{\circ} \mathrm{C}$ (Khanongnuch et al. 1998). The purified $\beta$-mannanase produced by HDYM-04 shows higher affinity toward glucomannan substrate $\left(K_{m}\right.$ and $V_{\max }$ were $2.69 \mathrm{mg} / \mathrm{mL}$ and $251.41 \mathrm{U} / \mathrm{mg}$, respectively) than that of other mannans like guar gum. But, the result was higher than that $\beta$-mannanase of Paenibacillus sp. DZ3 $\left(K_{\mathrm{m}} 1.05 \mathrm{mg} / \mathrm{mL}\right)$ to amorophophallus konjac (Mendoza et al. 1994), and $\beta$-mannanase of B.nealsonii PN-11 $\left(K_{\mathrm{m}} 11.59 \mathrm{mg} / \mathrm{mL}\right)$ to guar gum (Chauhan et al. 2014a, b). Kinetic studies revealed that the enzyme had more affinity toward natural glucomannan, and hence it was applicable in the food industry for the production of oligosaccharides. In the present study, the $\beta$-mannanase retained $>80 \%$ activity in dimethyl sulfoxide, acetone, chloroform, benzene, hexane. This could be due to wellknown fact that hydrophilic solvents are usually superior to hydrophobic solvents for the better enzyme activity, as the earlier have a greater tendency to bind water tightly, which is essential for catalytic activity. Similar results were observed with mannanase from $B$. subtilis G1 which showed 11-53\% reduction in enzyme activity by the addition of organic solvents ( $\mathrm{Vu}$ et al. 2012). In the presence of solvents; citric acid, ethylene diamine teracetic acid and potassium iodide, it retained $>80 \%$ residual activity. The strong inhibitory effect of cetyl trimethyl ammonium bromide, a potent cation surfactant, could be due to the destruction of the conformation of mannanase. 
Table 2 Effect of inhibitors, detergents, chelating agents, oxidizing agents and reducing agents on the activity of purified $\beta$-mannanase

\begin{tabular}{ll}
\hline Reagent & Relative activity (\%) \\
\hline Control & $100 \mathrm{a}$ \\
Inhibitors & \\
Citric acid & $87.53 \pm 2.34 \mathrm{~b}$ \\
Oxalic acid & $68.76 \pm 1.98 \mathrm{c}$ \\
Sodium thioglycolate & $45.34 \pm 2.67 \mathrm{~d}$ \\
Hydrogen & $37.29 \pm 1.34 \mathrm{de}$ \\
Phenylmethyl sulfonyl fluoride & $26.98 \pm 2.44 \mathrm{e}$ \\
Detergents & \\
Polyethylene glycol & $79.62 \pm 2.47 \mathrm{~b}$ \\
Cetyl trimethyl ammonium bromide & $14.15 \pm 1.21 \mathrm{f}$ \\
Chelating agents & \\
Ethylene diamine teraacetic acid & $82.43 \pm 1.23 \mathrm{~b}$ \\
Sodium citrate & $78.87 \pm 3.23 \mathrm{~b}$ \\
Sodium azide & $65.98 \pm 1.34 \mathrm{c}$ \\
Oxidizing agents & \\
Potassium iodide & $83.23 \pm 1.23 \mathrm{~b}$ \\
Ammonium persulfate & $66.37 \pm 1.19 \mathrm{c}$ \\
Hydrogen peroxide & $45.82 \pm 2.12 \mathrm{~d}$ \\
Reducing agents & \\
Ascorbic acid & $38.81 \pm 1.13 \mathrm{de}$ \\
Dithiothreitol & $27.63 \pm 2.41 \mathrm{e}$ \\
\hline
\end{tabular}

The $100 \%$ activity represented the control enzyme activity without any agents. Different letters represent significant differences $(p<0.05)$ relative to the control

Besides, we have found that the $\beta$-mannanase produced by HDYM-04 we used show remarkably high activity and found to be capable of decolorizing and degrading different structures of synthetic dyes. Though lots of papers reported the degradation and decolourisation of synthetic dyes by other enzymes, some studies demonstrating that laccases from Leptomitus lacteus could made different dyes decolorization (Svobodová et al. 2008). Such as, B.cereus could decolorize $85 \%$ of an azo dye for $120 \mathrm{~h}$ of incubation (Kanagaraj et al. 2012) and a novel laccase from B.subtilis WD23 could decolorize 50-90 \% of congo red and methyl orange, which suggested the potential application of spore laccase in dyestuff treatment (Wang et al. 2010a, b). Unfortunately, the majority of dyes are chemically stable and still resistant to microbiological attack. The differences in the decoloriaztion efficiencies may be attributed to the various chemical structures of different dyes. The most employed dyes belong to the azo and triaromatic class which accounts for the $80 \%$ of all textile dye produced. The best decolorization over was obtained with reactive conge red methyl orange and titan yellow. $\beta$-mannanase may be modify azo dye structures by destroying their chromophoric assemblies, phenoxyl radicals are generated in
Table 3 Decolourisation of dyes by $\beta$-mannanase produced by HDYM-04

\begin{tabular}{lrr}
\hline Dyes & \multicolumn{2}{c}{ Decolourisation (\%) } \\
\cline { 2 - 3 } & \multicolumn{1}{c}{$\mathbf{6 h}$} & $\mathbf{1 2} \mathbf{h}$ \\
\hline Methyl orange & $54.25 \pm 2.34 \mathrm{~b}$ & $99.04 \pm 0.03 \mathrm{a}$ \\
Aniline blue & $41.11 \pm 2.01 \mathrm{e}$ & $90.23 \pm 2.87 \mathrm{~b}$ \\
Alizarin & $23.86 \pm 2.12 \mathrm{e}$ & $83.63 \pm 2.89 \mathrm{c}$ \\
Water-soluble melanin & $64.83 \pm 2.56 \mathrm{a}$ & $68.13 \pm 3.56 \mathrm{~d}$ \\
Ponceau S & $11.72 \pm 1.55 \mathrm{f}$ & $60.49 \pm 3.88 \mathrm{~d}$ \\
Brilliant green & $6.57 \pm 0.56 \mathrm{~g}$ & $34.46 \pm 2.32 \mathrm{e}$ \\
Coomassie brilliant blue & $16.40 \pm 2.31 \mathrm{f}$ & $30.74 \pm 2.37 \mathrm{e}$ \\
Bromophenol blue & $11.40 \pm 1.76 \mathrm{f}$ & $27.52 \pm 2.34 \mathrm{e}$ \\
Bromothmol blue & $5.52 \pm 1.22 \mathrm{~g}$ & $27.14 \pm 2.87 \mathrm{e}$ \\
Solvent Red 24 & $11.12 \pm 1.87 \mathrm{f}$ & $23.28 \pm 2.23 \mathrm{ef}$ \\
Orange G6 & $3.08 \pm 0.23 \mathrm{~g}$ & $19.63 \pm 1.07 \mathrm{f}$ \\
Orange I & $5.67 \pm 0.78 \mathrm{~g}$ & $18.15 \pm 0.11 \mathrm{f}$ \\
Safranine T & $4.34 \pm 0.76 \mathrm{~g}$ & $17.39 \pm 2.82 \mathrm{f}$ \\
5,5'-Dibromo-o- cresolsulfonphthalein & $11.11 \pm 1.87 \mathrm{f}$ & $16.33 \pm 2.11 \mathrm{f}$ \\
Eosin Y & $14.78 \pm 2.11 \mathrm{f}$ & $16.19 \pm 1.76 \mathrm{f}$ \\
Neutral red & $0 \pm 0 \mathrm{~h}$ & $7.31 \pm 0.87 \mathrm{~g}$ \\
Methylene blue & $4.18 \pm 0.23 \mathrm{~g}$ & $4.29 \pm 0.28 \mathrm{~g}$ \\
Fast Green3 & $2.94 \pm 0.18 \mathrm{~g}$ & $2.94 \pm 0.29 \mathrm{gh}$ \\
Amaranth & $0.29 \pm 0.14 \mathrm{~h}$ & $1.25 \pm 0.11 \mathrm{~h}$ \\
Chromotrope 2R & $0.46 \pm 0.04 \mathrm{~h}$ & $0.68 \pm 0.09 \mathrm{~h}$ \\
Eosin & $0.29 \pm 0.01 \mathrm{~h}$ & $0.29 \pm 0.03 \mathrm{~h}$ \\
Alizarin yellow R & $0 \pm 0 \mathrm{~h}$ & $0 \pm 0 \mathrm{~h}$ \\
\hline
\end{tabular}

The different letters in the same column of the data indicate the level of significant differences at $p<0.05$

the reaction course (Muralikrishna et al. 1995). Compared with the $\beta$-mannanase produced by HDYM-04, these enzyme decolorization efficiency were relatively low. The $\beta$-mannanases are oxidase that cataluze oxidation reactions and hydrolysis reactions in many phenolic and organic substrates coupling with reduction reactions that transfer molecular oxygen to water (Murugesan et al. 2007). Triaromatic methane dyes represent an especially recalcitrant class of compounds. The present study confirms the ability of methyl orange and aniline blue purified $\beta$-mannanase to decolorize amaranth, chromotrope $2 \mathrm{R}$, amaranth and eosin with decolorization efficiency of more than $90 \%$ in short time. This could be due to the presense of electron donating methy and methoxy groups on the triaromatic methane dyes. The results obtained in this study were in agreement with results reported previrously for Pleurotusostreatus laccase (Kumar et al. 2012) and P.variabile laccase (Forootanfar et al. 2011). They also demonstrated that different decolorization rates were attributed to the specific catalytic properties of the individual enzymes and to the structure of dyes. To our knowledge, this is the first description of a bacterial $\beta$-mannanase from HDYM-04 able to degrade 

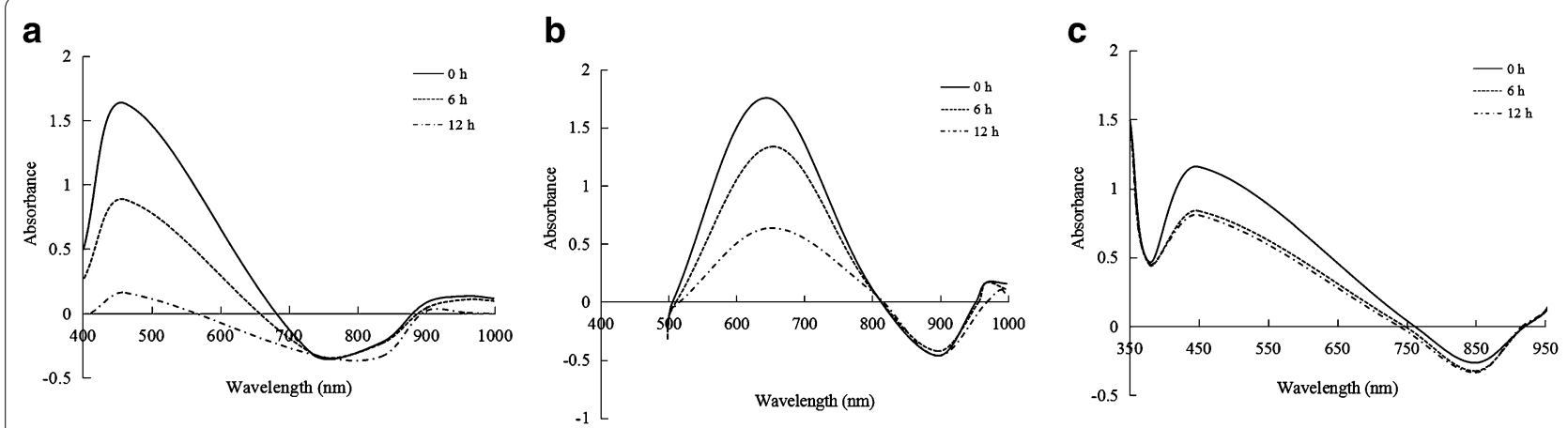

Fig. 4 Degradation of dyes by purified $\beta$-mannanase produced by HDYM-04 (a methyl orange, $\mathbf{b}$ aniline blue, $\mathbf{c}$ alizalin)

different dyes. Furthermore, the decolorization of dyes by $\beta$-mannanase produced by HDYM-04 is simple and cheap. So, the broad substrates specificity of enzyme rendered its great potentials in industrial applications, such as degradation of dyes from acidic textile effluents and the purified $\beta$-mannanase produced by HDYM- 04 could be successfully employed for the treatment of dyes bearing industrial wastewater as it had prominent capacity to degrade other different dyes. Some studies found that, the degradation of azo dyes could result in the production of compounds of increased toxicity. However, most studies failed to evaluate the toxicity of either the dyes and/or the reaction products (Gottlieb et al. 2003). So, to further investigate its effect on the toxicity of dye decolorization, the toxicity experiment will be carry out.

\section{Conclusions}

To sum up, the purified $\beta$-mannanase produced by HDYM-04 showed higher affinity toward glucomannan substrate $\left(K_{m}\right.$ and $V_{\max }$ were $2.69 \mathrm{mg} / \mathrm{ml}$ and $251.41 \mathrm{U} /$ $\mathrm{mg}$, respectively) than that of other mannans like guar gum. The enzyme obtained from this research possessed much higher stability in inhibitors, detergents, chelating agents, oxidizing agents and reducing agents. Furthermore, this enzyme could resist citric acid, ethylene diamine teraacetic acid and potassium iodide with more than $80 \%$ maximum activity remained. Besides, this study represented the first attempt to decolorize the mixtures of dyes by purified $\beta$-mannanase from HDYM- 04 . Thus, the $\beta$-mannanase has been successfully identified and, from this study, it has good potential in applying to decolorize dyes in textile wastewaters, particularly for water recycling. Further studies should be attempted to evaluate their feasibility in industrial uses.

\section{Authors' contributions}

JG and RD: these two authors contributed equally to this work, including literature research, experimental studies, manuscript preparation. DZ, GS and MJ: data collection and data analysis. WP: the corresponding author, acquisition of funding, study concepts, study design, final version approval. All authors read and approved the final manuscript.

\section{Author details}

${ }^{1}$ Key Laboratory of Microbiology, College of Life Science, Heilongjiang University, Harbin 150080, People's Republic of China. ${ }^{2}$ School of Chemical Engineering and Technology, Tianjin University, Tianjin 300072, People's Republic of China.

\section{Acknowledgements}

The research was supported by grants from the National Natural Science Foundation of China (No. 31270534), the National Natural Science Foundation of China (No. 31470537), the National Natural Science Foundation of China (No. 31570492), and the Science and Technology Innovation Team Construction Project of Heilongjiang Province (2012td009).

\section{Competing interests}

The authors declare that they have no competing interests.

Received: 14 April 2016 Accepted: 7 October 2016

Published online: 21 October 2016

\section{References}

Asgher M, Bhatti HN, Ashraf M, Legge RL (2008) Recent developments in biodegradation of industrial pollutants by white rot fungi and their enzyme system. Biodegradation 19:771-783

Bradford MM (1976) A rapid and sensitive method for the quantitation of microgram quantities of protein utilizing the principle of protein-dye binding. Anal Biochem 72:248-254

Brown MA, De Vito SC (1993) Predicting azo dye toxicity. Critical reviews in environmental science and technology 23:249-324

Cantarel BL, Coutinho PM, Rancurel C, Bernard T, Lombard V, Henrissat B (2009) The Carbohydrate-Active EnZymes database (CAZy): an expert resource for glycogenomics. Nucleic Acids Res 37:D233-D238

Chandra MRS, Lee YS, Park IH, Zhou Y, Kim KK, Choi YL (2011) Isolation, purification and characterization of a thermostable $\beta$-mannanase from Paenibacillus sp. DZ3. J Korean Soc Appl Biol Chem 54:325-331

Chauhan PS, Puri N, Sharma P, Gupta N (2012) Mannanases: microbial sources, production, properties and potential biotechnological applications. Appl Microbiol Biotechnol 93:1817-1830

Chauhan PS, George N, Sondhi S, Puri N, Gupta N (2014a) An overview of purification strategies for microbial mannanases. Int J Pharm Bio Sci 5:176-192

Chauhan PS, Sharma P, Puri N, Gupta N (2014b) Purification and characterization of an alkali-thermostable $\beta$-mannanase from Bacillus nealsonii $\mathrm{PN}-11$ and its application in mannooligosaccharides preparation having prebiotic potential. Eur Food Res Technol 238:927-936 
Dhawan S, Kaur J (2007) Icrobial mannanases: an overview of production and applications. Crit Rev Biotechnol 27:197-216

Erkurt EA, Ünyayar A, Kumbur H (2007) Decolorization of synthetic dyes by white rot fungi, involving laccase enzyme in the process. Process Biochem 42:1429-1435

Ferreira HM, Ferreira FEX (2004) Purification and characterization of a $\beta$-mannanase from Trichoderma harzianum strain T4. Carbohydr Polym 57:23-29

Forootanfar H, Faramarzi MA, Shahverdi AR, Yazdi MT (2011) Heterologous expression and characterisation of a laccase from Colletotrichum lagenarium and decolourisation of different synthetic dyes. Bioresour Technol 102:1808-1814

Ge JP, Du RP, Zhao D, Song G, Jin M, Ping WX (2016) Bio-chemical characterization of a $\beta$-mannanase from Bacillus licheniformis HDYM-04 isolated from flax water-retting liquid and its decolorization ability of dyes. RSC Adv 6:23612-23621

Gottlieb A, Shaw C, Smith A, Wheatley A, Forsythe S (2003) The toxicity of textile reactive azo dyes after hydrolysis and decolourisation. J Biotechnol 111:49-56

Jiang Z, Wei Y, Li D, Li L, Chai PP, Kusakabe I (2006) High-level production, purification and characterization of a thermostable $\beta$-mannanase from the newly isolated Bacillus subtilis WY34. Carbohydr Polym 66:88-96

Kanagaraj J, Senthil Velan T, Mandal AB (2012) Biological method for decolourisation of an azo dye: clean technology to reduce pollution load in dye waste water. Clean Techn Environ Policy 14:565-572

Kaushik P, Malik A (2009) Fungal dye decolourization: recent advances and future potential. Environ Int 35:127-141

Khanongnuch C, Asada K, Tsuruga H, Ooi T, Kinoshita S, Lumyong S (1998) $\beta$-Mannanase and xylanase of Bacillus subtilis $5 \mathrm{H}$ active for bleaching of crude pulp. J Ferment Bioeng 86:461-466

Kumar V, Sathyaselvabala V, Premkumar MP, Vidyadevi T, Sivanesan S (2012) Biochemical characterization of three phase partitioned laccase and its application in decolorization and degradation of synthetic dyes. J Mol Catal B Enzym 72:63-72

Liepman AH, Nairn CJ, Willats WG, Sørensen I, Roberts AW, Keegstra K (2007) Functional genomic analysis supports conservation of function among cellulose synthase-like a gene family members and suggests diverse roles of mannans in plants. Plant Physiol 143:1881-1893

Mendoza N, Arai M, Kawaguchi T, Cubol FS, Panerio EG, Yoshida T, Joson LM (1994) Isolation of mannan-utilizing bacteria and the culture conditions for mannanase production. World J Microbiol Biotechnol 10:51-54

Miller GL (1959) Use of dinitrosalicylic acid reagent for determination of reducing sugar. Anal Chem 31:426-428

Muralikrishna C, JackT, Spadaro V (1995) Renganathan lignin peroxidasecatalyzed oxidation of sulfonated azo dyes generates novel sulfophenyl hydroperoxides. Biochemistry 34:7765-7772
Murugesan K, Nam IH, Kim YM, Chang YS (2007) Decolorization of reactive dyes by a thermostable laccase produced by Ganoderma lucidum in solid state culture. Enzyme Microb Technol 40:1662-1672

Scheller HV, Ulvskov P (2010) Hemicelluloses. Plant Biol 61:263

Songsiriritthigul C, Buranabanyat B, Haltrich D, Yamabhai M (2010) Efficient recombinant expression and secretion of a thermostable GH26 mannan endo-1,4- $\beta$-mannosidase from Bacillus licheniformis in Escherichia coli. Microb Cell Fact 9:312-332

Svobodová K, Majcherczyk A, Novotný Č, Kües U (2008) Implication of mycelium-associated laccase from Irpex lacteus in the decolorization of synthetic dyes. Bioresour Technol 99:463-471

Takahash R, Kusakabe I, Kobayashi H, Murakami K, Maekawa A, Suzuki T (1984) Purification and some properties of mannanase from Streptomyces sp. Agric Biol Chem 48:2189-2195

Van Zyl WH, Rose SH, Trollope K, Görgens JF (2010) Fungal $\beta$-mannanases: mannan hydrolysis, heterologous production and biotechnological applications. Process Biochem 45:1203-1213

Vu TT, Quyen DT, Dao TT, Nguyen SLT (2012) Cloning, high-level expression, purification, and properties of a novel endo- $\beta-1,4$-mannanase from Bacillus subtilis G1 in Pichia pastoris. J Microbiol Biotechnol 22:331-338

Wang CL, Zhao M, Li DB (2010a) Isolation and characterization of a novel Bacillus subtilis WD23 exhibiting laccase activity from forest soil. Afr J Biotechnol 9:5496-5502

Wang H, Luo H, Li J, Bai YG, Huang HQ, Shi PJ, Fan YL, Yao B (2010b) An a-galactosidase from an acidophilic Bispora sp. MEY-1 strain acts synergistically with $\beta$-mannanase. Bioresour Technol 101:8376-8382

Zahura UA, Rahman MM, Inoue A, Tanaka H, Ojima T (2011) cDNA cloning and bacterial expression of an endo- $\beta-1,4-$ mannanase, AkMan, from Aplysia kurodai. Comp Biochem Physiol 159:227-235

Zakaria M, Yamamoto S, Yagi T (1998) Purification and characterization of an endo-1,4- $\beta$-mannanase from Bacillus subtilis KU-1. FEMS Microbiol Lett 158:25-31

Zeilinger S, Kristufek D, Arisan-Atac I, Hodits R, Kubicek CP (1993) Conditions of formation, purification, and characterization of an alpha-galactosidase of Trichoderma reesei RUT C-30. Appl Environ Microbiol 59:1347-1353

Zhang J, He Z, Hu K (2000) Purification and characterization of $\beta$-mannanase from Bacillus licheniformis for industrial use. Biotechnol Lett 22:1375-1378

Zhou J, Zhang R, Gao Y, Li JJ, Tang XH, Mu YL, Wang F, Li C, Dong YY, Huang ZX (2012) Novel low-temperature-active, salt-tolerant and proteases-resistant endo-1, 4- $\beta$-mannanase from a new Sphingomonas strain. J Biosci Bioeng 113:568-574

\section{Submit your manuscript to a SpringerOpen ${ }^{\circ}$ journal and benefit from:}

- Convenient online submission

- Rigorous peer review

- Immediate publication on acceptance

- Open access: articles freely available online

- High visibility within the field

- Retaining the copyright to your article

Submit your next manuscript at $\boldsymbol{\nabla}$ springeropen.com 